Таміла ДЖАМАН,

кандидат педагогічних наук, дочент, завідувач кабінету виховної роботи та позашкільної освіти Рівненського обласного інституту післядипломної педагогічної освіти, м. Рівне, Україна

ORCID: 0000-0003-2257-0875

e-mail:jaman-tv@ukr.net

\title{
ВЗАЕМОЗВ'ЯЗОК КРИТЕРІЇВ ТА ПОКАЗНИКІВ ЕФЕКТИВНОСТІ НЕПЕРЕРВНОЇ ПІДГОТОВКИ ВЧИТЕЛІВ ПОЧАТКОВОЇ ШКОЛИ ДО ОСВІТНЬОЇ ДІЯЛЬНОСТІ В УМОВАХ ІНКЛЮЗИВНОГО НАВЧАННЯ
}

Анотація. Статтю присвячено актуальній педагогічній проблемі - діагностиці готовності вчителів початкової школи до освітньої діяльності в умовах інклюзивного навчання. Окреслено загальні вимоги до критеріїв, а також досліджено взаємозв'язок критерїв та показників у системі неперервної підготовки вчителів початкової школи до роботи в інклюзивному освітньому середовищі. На основі теоретичного аналізу и узагальнення даних експериментальних досліджень, власного педагогічного досвіду виявлено, щзо готовність вчителя до роботи в умовах інклюзивного навчання - ие єдність чотирьох компонентів: мотиваційно-ціннісного, когнітивно-діяльнісного, особистісно-рефлексивного та комунікативного. Означені компоненти реалізуються за допомогою мотиваційно-аксіологічного, пізнавально-процесуального, рефлексивно-оцінного, діяльнісно-комунікативного критерії, до кожного з яких дібрано однакову кількість показників для оптимізації процесу діагностики. Відповідно до критеріїв виокремлено високий, достатній, середній та низький рівні підготовки вчителів для освітньої діяльності в умовах інклюзивного навчання.

Ключові слова: готовність учителів до роботи в умовах інклюзивного навчання, компоненти, критерії, показники та рівні вияву критерїв.

Tamila DZHAMAN,

PhD in Pedagogy, Associate Professor,

Head of the office of Educational work and

extracurricular activity

in Rivne Regional Institute

of Postgraduate Pedagogical Education,

Rivne, Ukraine

ORCID: 0000-0003-2257-0875

e-mail:jaman-tv@ukr.net

\section{RELATIONSHIP OF THE CRITERIA AND INDICATORS EFFECTIVENESS OF CONTINUOUS TRAINING OF THE PRIMARY SCHOOL TEACHER TO THE WORK IN THE CONDITIONS OF INCLUSIVE EDUCATION}

\begin{abstract}
This article is dedicated to the relevant pedagogical problem - diagnostic of primary school teachers 'readiness to the work in conditions of inclusive education. The system of continuous primary school teachers training to work in the inclusive education conditions should contain all components of organization the educational process on each stages of its implementation, therefore we think, that diagnostic is very important, because a specialy it gives us an opportunity to clarify the state of functioning the pedagogical system to create the required conditions for the proper educational process management. The purpose of the article is to explore the relationships of criteria and indicators in the system of continuous primary school teachers' training to the work in the inclusive education environment. The stages of continuous teacher training to
\end{abstract}

the work in inclusive education conditions are determined not only by the degree of formation of the components, but also by taking into account the continuity, draduality of the process, gradual complication, widening the activity sphere, increasing the complexity of educational tasks in the professional context. On the basis of theoretical analysis and data generalization of experimental studies of author's pedagogical experience it was found that teachers' readiness to work in the inclusive education conditions is considered as the unity of four components: motivational value, cognitive activity, personal reflective and communicative components. It was generalized that the overall level of readiness of future teachers to work in inclusive education conditions depends on the level of formation of each component that was characterized. That's why, in the educational process 
on pedagogical faculties, we should use technology, methods and teaching aids that will provide the optimal conditions for the formation of all components of the professional training, providing the influence on the motivational, intelectual, emotional, reflexive and communicative spheres of student's and teacher's activity. These components were realized by the motivational, axiological, cognitiveprocedural, reflective and evaluative and communicative criteria. The same amounts of indicators were selected for each component to optimize the process of diagnostics. According to the criteria, such stages of teachers' training for educational activity in the inclusive education conditions were separated: height, intermediate, middle and low.

Key words: teachers' readiness to the work in inclusive education conditions, diagnostics, components, criteria, indicators and the levels of detection of criteria.

Постановка проблеми. Постійне вдосконалення системи підготовки та підвищення кваліфікації вчителів початкової школи зумовлене зміною ролі людини в сучасному світі, баченням ідеалу освіченості особистості та висуванням нових вимог до якості людського капіталу відповідно до культурно-духовних, суспільно-економічних і технологічних трансформацій, а також чисельних викликів глобального, європейського, національного, регіонального та місцевого рівнів.

Реалізація державної політики в царині інклюзії передбачає підготовку компетентних учителів, здатних усвідомити нові способи організації освітнього простору, опанувати сучасні технології й методики навчання дітей в інклюзивних класах. Система неперервної підготовки вчителів початкової школи до професійної діяльності в умовах інклюзивного навчання має комплексно охоплювати всі складники організації освітнього процесу на всіх етапах їі впровадження, тому вважаємо, що діагностика має особливе значення, оскільки дає змогу з'ясувати стан функціонування педагогічної системи для створення належних умов ефективного управління освітнім процесом.

Водночас педагогічні дослідження констатують наявність суперечностей між соціальним замовленням суспільства на розвиток інклюзивної освіти та недостатністю професійної підготовки вчителів початкової школи до роботи в інклюзивному освітньому середовищі, відсутністю розробленого діагностичного інструментарію для проведення експериментальних досліджень, нерозробленістю навчально-методичного забезпечення інклюзивного навчання.

Аналіз наукових досліджень і публікацій охоплював такі напрями: готовність учителів початкової школи до роботи в умовах інклюзивного навчання, її компонентна структура (С. Альохіна, Г. Алексєєва, О. Безпалько, В. Бондар, I. Демченко, О. Мартинчук, І. Оралканова, Т. Соловей, В. Хитрюк, Г. Цехмістрова, М. Чайковський, 3. Шевців, Ю. Шуміловська та ін.); сутність ключових понять («діагностика», «моніторинг», «компоненти», «критерії», «показники», «рівні готовності вчителів») та особливості їхнього застосування в експериментальних дослідженнях, присвячених інклюзивній освіті (Ю. Бойчук, О. Бородіна, О. Микитюк, Н. Бодруг, В. Вербець, А. Денисенко, К. Інгекамп, О. Красовська, А. Киверялг, М. Левшин, В. Луговий, С. Мартиненко, В. Ортинський, І. Підласий, В. Сластьонін).
Узагальнення результатів теоретичного аналізу, синтез даних експериментальних досліджень доводять неабияке зацікавлення українських педагогів проблемами діагностики й методики проведення оцінювання освітніх результатів. Крім того, існує неузгодженість і суперечливість поглядів на структурно-змістове наповнення ключових понять, що передбачає необхідність нових теоретико-експериментальних досліджень.

Мета статті полягає у дослідженні взаємозв'язку критеріїв та показників у системі неперервної підготовки вчителів початкової школи до роботи в інклюзивному освітньому середовищі.

Виклад основного матеріалу дослідження. Великий тлумачний словник сучасної української мови термін «критерій» визначає як мірило, підставу для оцінки, визначення або класифікації чогось (Бусел, 2004 , с. 465). Суголосними із цим твердженням $є$ думки С. Гончаренка, який зауважує, що для педагогічної науки питання критеріїв, якими можна керуватися в процесі оцінювання педагогічних процесів і явищ, $\epsilon$ надзвичайно важливим (Гончаренко, 2011), та 3. Шевців, яка у своїх експериментальних дослідженнях під критерієм розуміє «деякі найбільш загальні характеристики, котрі об'єднують у собі ряд простих показників» (Шевців, 2016, с. 129). Отже, на думку вчених, які досліджують проблеми діагностики, критерій $€$ ознакою, за якою класифікуються та оцінюються явища, дії або діяльність, тобто критерій можна вважати маркером, що дає змогу об'єктивно оцінити динаміку й результативність експериментального дослідження (Сластьонін, 1991).

Зауважимо, що в педагогіці визначено загальні вимоги до критеріїв. За твердженнями науковців (В. Беспалько, Н. Бодруг, С. Вітвицька, А. Киверялг, I. Підласий та ін.), вони мають відображати особливості досліджуваного явища, бути об'єктивними, однорівневими (жоден критерій одночасно не може бути складником іншого), адекватними явищу, яке вимірюється. Відповідно саме за критеріями встановлюються зв'язки між усіма компонентами системи неперервної освіти вчителів до роботи в інклюзивному середовищі; вони мають чітко визначатися та бути придатними для вимірювання традиційними оцінювальними засобами, розкриватися через низку показників, за якими можна визначити більшу чи меншу міру вираження певного критерію, відображати динаміку вимірюваної якості в часі та просторі, а якісні показники при цьому мають виступати в єдності з кількісними та доповнювати один одного тощо (Беспалько, 1995; Бодруг, 2014; Вітвицька, 2003; Киверялг, 1980; Підласий, 1998). Отже, критерії $є$ загальним поняттям, особливості якого конкретизуються в показниках, що характеризують певний прояв чогось і підлягають діагностичному вимірюванню. Серед показників учені вирізняють якісні (наявність або відсутність певної властивості) та кількісні (міра вираження властивості) (Чайковський, 2012). Розглянемо аналізовані поняття детальніше, враховуючи особливості нашого дослідження.

Грунтуючись на теоретичному аналізі й узагальненні даних наукових досліджень, ми вважаємо, що неперервна підготовка до професійної діяльності в інклюзивному освітньому середовищі - це єдність чотирьох компонентів: мотиваційно-ціннісного, когнітивно-діяльнісного, особистісно-рефлексійного та комунікативного. Стисло схарактеризуємо кожен із них. 
Мотивачійно-иіннісний компонент пов'язаний 3 усвідомленням ціннісних аспектів педагогічної діяльності в умовах інклюзивного навчання, iіï професійної значущості, розумінням важливості загальнопедагогічних та специфічних для інклюзії знань, умінь, навичок, набуття досвіду діяльності, позитивного емоційного ставлення до навчально-пошукової діяльності, саморозвитку й самовдосконалення.

Когнітивно-діяльнісний компонент передбачає наявність необхідного обсягу теоретичних знань у царині інклюзивної педагогіки, фахових предметів, навчально-виховної роботи, здатність до аналітичної діяльності, креативність мислення тощо.

Особистісно-рефлексивний компонент безпосередньо спрямований на рефлексію, самооцінку власного рівня готовності до вирішення професійних завдань в інклюзивній освіті, прагнення до подальшого вдосконалення педагогічних умінь, самостійного пошуку інформації для саморозвитку, самовдосконалення й самореалізації.

Комунікативний компонент неперервної підготовки вчителів до роботи в умовах інклюзивного навчання характеризує особливості взаємодії вчителя і учня в процесі досягнення дидактичної мети.

Отже, загальний рівень готовності майбутніх педагогів до професійної діяльності в умовах інклюзивного навчання залежить від ступеня сформованості кожного 3 представлених вище компонентів. Тому в освітньому процесі студентів, майбутніх учителів початкових класів, слід використовувати такі технології, методи, засоби навчання, які забезпечать оптимальні умови для формування всіх компонентів професійної підготовки, забезпечення впливу на мотиваційну, інтелектуальну, емоційну, рефлексивну й комунікативну сфери їхньої діяльності. Уважаємо, що рівні підготовленості вчителів початкової школи до роботи в умовах інклюзивного навчання можна визначити за чотирма критеріями, які корелюються зі змістовими компонентами цього складного поняття.
Для педагогічних досліджень важливе визначення критеріїв компонентів того процесу, на який спрямовано нашу наукову розвідку. Розглянемо критерії та показники, за якими визначається результат означеного педагогічного дослідження й методики реалізації сукупності умов, за яких система неперервної підготовки вчителів початкової школи для освітньої діяльності в інклюзивному освітньому просторі буде ефективною.

Отже, в нашому дослідженні під критеріями готовності педагогів до роботи в умовах інклюзивного навчання розуміється матеріалізована ознака, за допомогою якої оцінюється ступінь досягнення мети, кількісна міра певного явища, а показник виступає конкретним проявом сутності якості процесу чи явища. Тобто критерій як загальна характеристика педагогічного явища чи об'єкта може мати не один, а багато показників.

На основі аналізу теоретичних та експериментальних досліджень, а також особливостей компонентного складу неперервної підготовки вчителів початкової школи для освітньої діяльності в умовах інклюзивного навчання визначено такі критерії: мотиваиійно-аксіологічний для діагностики мотиваційно-ціннісного компонента неперервної підготовки вчителів початкової школи до роботи в інклюзивному освітньому середовищі; пізнавально-процесуальний для визначення рівня фахових знань і здатності застосовувати їх у практичній діяльності, наявність досвіду в межах когнітивно-діяльнісного компонента; рефлексивно-оиінний для діагностики особистісно-рефлексивного компонента готовності до роботи в умовах інклюзивного навчання; діяльнісно-комунікативний для моніторингу рівня сформованості комунікативної компетентності вчителів початкової школи в межах комунікативного компонента.

До кожного критерію з метою оптимізації процесу діагностики ми підібрали однакову кількість показників (п'ять). Взаємозв'язок критеріїв та показників у системі неперервної підготовки вчителів початкової школи до освітньої діяльності в умовах інклюзивного навчання узагальнено в таблииі.

\section{Критерії та показники готовності вчителів початкової школи до роботи в умовах інклюзивного навчання}

\begin{tabular}{|c|c|}
\hline Критерії & Показники \\
\hline $\begin{array}{l}\text { Мотиваційно- } \\
\text { аксіологічний }\end{array}$ & $\begin{array}{l}\text { Наявність мотивів і цінностей, адекватних цілям і завданням інклюзивної освіти: } \\
\text { - усвідомлення цінності й значущості інклюзивної освіти, важливості спільного навчання } \\
\text { дітей з особливими освітніми потребами в закладах загальної середньої освіти; } \\
\text { - виявлення особистої зацікавленості у вирішенні питань інклюзивної освіти; } \\
\text { - демонстрування ціннісного ставлення до дітей з особливими потребами; } \\
\text { - мотивування себе на виконання певних дій і досягнення успіху в організації спільного } \\
\text { навчання дітей із нормальним розвитком і особливими освітніми потребами; } \\
\text { - позитивна мотиваційно-ціннісна спрямованість щодо роботи в інклюзивному } \\
\text { освітньому середовищі, готовність навчатися впродовж усього життя }\end{array}$ \\
\hline $\begin{array}{l}\text { Пізнавально- } \\
\text { процесуальний }\end{array}$ & $\begin{array}{l}\text { Сформованість інклюзивної компетентності: } \\
\text { - наявність загальнопедагогічних, фахових знань та знання філософії, принципів і } \\
\text { завдань інклюзивної освіти; } \\
\text { - розуміння психолого-педагогічних особливостей вікового й особистого розвитку дітей } \\
\text { з особливими потребами; } \\
\text { - здатність обирати оптимальні способи організації інклюзивного навчання, проєктувати } \\
\text { освітній процес для спільного навчання; } \\
\text { - здатність створювати корекційно-розвивальне середовище в умовах інклюзивного } \\
\text { навчання, використовувати ресурси й можливості закладу освіти для розвитку всіх без } \\
\text { винятку дітей; } \\
\text { - прагнення здійснювати професійну самоосвіту з питань організації інклюзивного } \\
\text { навчання }\end{array}$ \\
\hline
\end{tabular}


Продовження таблиці

\begin{tabular}{|c|c|}
\hline Критерії & Показники \\
\hline $\begin{array}{l}\text { Рефлексивно- } \\
\text { оцінний }\end{array}$ & $\begin{array}{l}\text { Сформованість рефлексивної компетентності: } \\
\text { - здатність учителя початкової школи до професійної рефлексії, зокрема вміння } \\
\text { аналізувати мету, завдання професійних змін, а також проблеми й труднощі у власній } \\
\text { педагогічній діяльності стосовно інклюзивного навчання; } \\
\text { - здатність проводити аналіз наявних ресурсів та можливостей для проєктування й } \\
\text { реалізації спільного навчання дітей із нормальним розвитком та з особливими освітніми } \\
\text { потребами; } \\
\text { - спроможність проводити самооцінку вибору методів і способів організації інклюзивного } \\
\text { навчання; } \\
\text { - здатність здійснювати контроль за своїми діями в процесі організації інклюзивного } \\
\text { навчання; } \\
\text { - спроможність проводити оцінку результатів навчання, орієнтованого на розвиток усіх } \\
\text { дітей і соціалізацію дітей з особливими освітніми потребами }\end{array}$ \\
\hline $\begin{array}{c}\text { Діяльнісно- } \\
\text { комунікативний }\end{array}$ & $\begin{array}{l}\text { Сформованість комунікативної компетентності в учителів початкової школи: } \\
\text { - обізнаність із жанрами педагогічного дискурсу, типами комунікативних стратегій } \\
\text { і тактик, переконливість аргументів у спілкуванні; } \\
\text { - уміння аналізувати та моделювати комунікативні ситуації (ситуації спілкування); } \\
\text { - здатність працювати в колективі (команді, групі), співпрацювати з різними людьми, } \\
\text { виявляти гнучкість у спілкуванні, вирішувати педагогічні конфлікти; } \\
\text { - уміння здійснювати самоаналіз і самооцінювання комунікативних актів; } \\
\text { - здатність налагоджувати взаємодію між усіма учасниками інклюзивного освітнього } \\
\text { процесу }\end{array}$ \\
\hline
\end{tabular}

Як бачимо, кожен з означених вище критеріїв схарактеризовано за допомогою комплексу показників, що репрезентують дані про стан і ступінь підготовленості педагогів до здійснення освітньої діяльності в інклюзивному середовищі, внаслідок чого надається оцінка якості процесу іiї здійснення.

Висновки. Отже, зважаючи на представлений у дослідженні матеріал, зазначимо, що окреслені компоненти готовності вчителів до професійної діяльності в умовах інклюзивного навчання, які корелюють із критеріями та показниками, рівнями їх вияву, не лише забезпечують цілісне бачення системи неперервної підготовки вчителів початкової школи до освітньої діяльності в умовах інклюзивного навчання, а й сприяють переходу до конкретного плану дій щодо здійснення моніторингу ефективності системи, надають можливість активного втручання в підготовку вчителів початкової школи до роботи в умовах інклюзивного освітнього середовища 3 метою її корекції.

Перспективами подальших досліджень у даному напрямі вважаємо створення комплексу методів для діагностики та моніторингу ефективності процесу неперервної підготовки вчителів початкової школи до роботи в умовах інклюзивного навчання, розроблення навчально-методичного супроводу та виокремлення організаційно-педагогічних умов і адекватних їм форм, засобів, методів і прийомів навчання.

\section{СПИСОК ВИКОРИСТАНОЇ ЛІТЕРАТУРИ}

Великий тлумачний словник сучасної української мови. (2004) / гол. ред. В. Г. Бусел. Ірпінь: ВТФ «Перун». $1440 \mathrm{c}$.

Гончаренко, С. У. (2011). Український педагогічний словник. 2-е вид., доп. й випр. Рівне: Волинські обереги. $552 \mathrm{c}$.

Шевців, 3. (2016). Діагностика сформованості соціально-педагогічної компетентності у майбутнього вчителя початкових класів. Педагогічні науки: збірник наукових праць Херсонського державного університету. Вип. LXXIII. T. 2. С. 127-133.
Сластенин, В. А. (1991). Диагностика профессиональной пригодности молодежи к педагогической деятельности. Москва: МГПИ. 287 с.

Беспалько, В. П. (1995). Педагогика и прогрессивные технологии обучения. Москва: Педагогическое общество России. 236 с.

Бодруг, Н. А. (2014). Компоненты, критерии, показатели и уровни сформированности педагогического мастерства будущих учителей. Sciarticle.ru: электронный периодический научный журнал. № 12. С. 173-180.

Вітвицька, С. (2003). Основи педагогіки вищої школи. Київ: Центр навчальної літератури. 316 с.

Кыверялг, А. (1980). Методы исследования в профессиональной педагогике. Таллин: Валгус. 334 с.

Підласий, І. П. (1998). Діагностика та експертиза педагогічних проектів. Київ: Україна. 343 с.

Чайковський, М. (2012). Інклюзивна компетентність як складова професійної компетентності суб' єктів навчально-виховного процесу. Педагогіка і психологія професійної освіти. № 2. С.15-21.

\section{REFERENCES}

Velykyi tlumachnyi slovnyk suchasnoi ukrainskoi movy [Large explanatory dictionary of the modern Ukrainian language]. (2004) / hol. red. V. H. Busel. Irpin: VTF «Perun». 1440 s. [in Ukrainian].

Honcharenko, S. U. (2011). Ukrainskyi pedahohichnyi slovnyk [Ukrainian pedagogical dictionary]. 2-e vyd., dop. y vypr. Rivne: Volynski oberehy. 552 s. [in Ukrainian].

Shevtsiv, Z. (2016). Diahnostyka sformovanosti sotsialno-pedahohichnoi kompetentnosti u maibutnoho vchytelia pochatkovykh klasiv [Diagnosis of the formation of socio-pedagogical competence in the future primary school teacher]. Pedahohichni nauky: zbirnyk naukovykh prats Khersonskoho derzhavnoho universytetu. Vyp. LXXIII. T. 2. S. 127-133. [in Ukrainian].

Slastenin, V. A. (1995). Diagnostika professionalnoy prigodnosti molodezhi k pedagogicheskoy deyatelnosti 
[Diagnostics of the professional suitability of young people for teaching]. Moskva: MGPI. 287 s. [in Russian].

Bespalko, V. P. (1995). Pedagogika i progressivnyie tehnologii obucheniya [Pedagogy and progressive learning technologies]. Moskva: Pedagogicheskoe obschestvo Rossii. 236 s. [in Russian].

Bodrug, N. A. (2014). Komponentyi, kriterii, pokazateli i urovni sformirovannosti pedagogicheskogo masterstva buduschih uchiteley [Components, criteria, indicators and levels of formation of pedagogical skills of future teachers]. Sciarticle.ru: elektronnyiy periodicheskiy nauchnyiy zhurnal. № 12. S. 173-180. [in Russian].

Vitvytska, S. (2003). Osnovy pedahohiky vyshchoi shkoly [Fundamentals of higher school pedagogy]. Kyiv: Tsentr navchalnoi literatury. 316 s. [in Ukrainian].

\section{УДК 378:004}

DOI: 10.37026/2520-6427-2021-105-1-110-114
Kyiveryalg, A. (1980). Metodyi issledovaniya v professionalnoy pedagogike [Research methods in professional pedagogy]. Tallin: Valgus. 334 s. [in Russian].

Pidlasyi, I. P. (1998). Diahnostyka ta ekspertyza pedahohichnykh proektiv [Diagnosis and examination of pedagogical projects]. Kyiv: Ukraina, 1998. $343 \mathrm{~s}$. [in Ukrainian].

Chaikovskyi, M. (2012). Inkliuzyvna kompetentnist yak skladova profesiinoi kompetentnosti sub'iektiv navchalno-vykhovnoho protsesu [Inclusive competence as a component of professional competence of subjects of educational process]. Pedahohika i psykholohiia profesiinoi osvity. № 2. S.15-21. [in Ukrainian].

Дата надходження до редакиї: 14.12.2020 p.

\section{ПЕДАГОГІЧНА ВЗАЕМОДІЯ ЗАКЛАДУ ДОШКІЛЬНОЇ ОСВІТИ І СІМ'Ï ІЗ ЗАСТОСУВАННЯМ ЦИФРОВИХ ТЕХНОЛОГІЙ У ПРОЦЕСІ ДИСТАНЦИЙНОГО НАВЧАННЯ}

\begin{abstract}
Анотація. У статті обтрунтовано проблему педагогічної взаємодії закладу дошкільної освіти та сім'ї завдяки застосуванню ицфрових технологій у прочесі дистаниійного навчання, спричиненого пандемією Covid-19. Зроблено акиент на використанні иифрових технологій в освітньому прочесі закладу дошкільної освіти, зокрема створенні фото- та відеопрезентацій, відеороликів, оголочень, методичних рекомендацій, інструкцій для батьків, фотоальбомів. Представлено досвід використання закладами дошкільної освіти у роботі з батьками соціальних мереж, мобільних додатків (вайбер-груп, блогів), онлайн-платформ (Google Classroom, ZOOM). Cхарактеризовано методику використання відеоконфе-
\end{abstract}

ренцій як телекомунікаційну технологію. Визначено, мо важливу роль у педагогічній взаємодії закладу дошкільної освіти та батьків відіграє сайт закладу освіти, де розміщено всю необхідну інформацію щзодо виховного проиесу. Окреслено вимоги до проведення фото- $і$ відеозйомок в освітній та виховній діяльності закладу дошкільної освіти. Доведено, щяо вплив ичирових технологій на життя сім'ї та закладу дошкільної освіти вимагає врахування сучасних тендениій розвитку циифрового суспільства, зокрема оновлення форм і методів роботи з батьками.

Ключові слова: педагогічна взаємодія, иифрові технології, відеоконференція, відеоролики, вайбер-групи, дистаниійне навчання, соиіальні мережі.

\section{Larisa LIAKHOTSKA,}

PhD in Pedagogy, Associate Professor,

Professor of the Department of Open Education Systems and Information Communication Technologies,

State Higher Educational Institution «University of

Educational Management»,

Kyiv, Ukraine

ORCID: 0000-0002-9690-8376

e-mail: lyahotska@ua.fm

\section{PEDAGOGICAL INTERACTION OF PRESCHOOL EDUCATIONAL INSTITUTION AND FAMILY WITH USING OF DIGITAL TECHNOLOGIES IN THE PROCESS OF DISTANCE LEARNING}

\author{
Abstract. The author takes notice of a problem on \\ organizing and quality of undertaking an educational
}

process based on the digital technologies under the global quarantine related to Covid-19 at educational institu- 